\title{
Demonstration of lymphoid antigens in decalcified bone marrow trephines
}

\author{
P A HALl,* R LindeMAN $\dagger$, M G BUTLER,* J A L AMESS, $\dagger$ A J D'ARDENNE*
}

From the Departments of ${ }^{*}$ Histopathology, $†$ Haematology and the $\ddagger$ Imperial Cancer Research Fund, Department of Medical Oncology, St Bartholomew's Hospital, London

SUMmARY A panel of antibodies recognising lymphoid and epithelial antigens in formalin fixed, paraffin embedded sections was applied to a series of 54 bone marrow trephines decalcified by formic or edetic acids. Normal trephines and cases infiltrated by myeloid, lymphoid, and epithelial tumours were included. Patterns of reactivity were distinct and allowed the different diseases to be distinguished. All lymphoid tumours expressed leucocyte common antigen, with B cell tumours staining with MB1 and MB2, and T cell tumours staining with MT1 and UCHL1. T cell acute lymphoblastic leukaemia (ALL)/lymphoblastic lymphoma all stained with MT1, but some were negative with UCHL1. B cell ALL/lymphoblastic lymphoma also stained with MT1, but could be distinguished by its reactivity with MB1 and MB2. Reed-Sternberg cells did not stain with any reagent. Normal and neoplastic myeloid cells stained with MT1. Carcinomas stained with CAM 5.2 but were negative for lymphoid markers except MB2 staining in some cases. A case of neuroblastoma could be distinguished from ALL/lymphoblastic lymphoma by its lack of reactivity with all antileucocyte antibodies and its staining with antineurone specific enolase. Although not ideal, if used together, this panel of reagents may usefully be applied to routinely fixed and processed, decalcified bone marrow trephines.

Many haemopoietic antigens, which currently can be shown, do not survive conventional fixation or decalcification. The examination of bone marrow trephines using immunohistochemical techniques is hampered by the difficulty of cutting suitable cryostat sections of calcified bone. Several studies have been reported which show that such sections can be cut, and that the information obtained from them may be of diagnostic value. ${ }^{1-4}$ Other workers have used immunohistochemical methods with bone marrow aspirate preparations. ${ }^{56}$ As many laboratories do not have the facilities for sophisticated cryostat methods, however, and as most trephines are conventionally fixed, decalcified, and processed, it would be useful to be able to recognise lymphoid antigens in such material.

Immunoreactivity of some antigens will survive decalcification after fixation. ${ }^{7-9}$ Some studies have described the use of immunohistochemical methods in conventionally processed trephines, but these have largely been concerned with the characterisation of immunoglobulins, ${ }^{10-12}$ or non-lymphoid tumour

Accepted for publication 17 February 1987 markers. ${ }^{1314}$ Recently several reagents have been described which permit the reliable demonstration of lymphoid subsets and epithelial markers in paraffin section. ${ }^{15-19}$ This study describes the successful use of these in a series of conventionally fixed and decalcified bone marrow trephines.

\section{Material and methods}

Cases were selected from the files of the haematology and histopathology departments at this hospital. All cases of lymphoid neoplasm had already been characterised immunophenotypically. Trephines had been fixed in unbuffered formol saline. About half had been decalcified in saturated edetic acid $(10-12 \%)$, with the addition of normal sodium hydroxide until the solution cleared, and the remainder in $5 \%$ formic acid in distilled water. All trephines were decalcified for 30 hours. Tissues were processed into paraffin wax, and consecutive $4 \mu \mathrm{m}$ sections were cut and attached to glass slides with $0.01 \%$ poly-L-lysine and dried overnight at $56^{\circ} \mathrm{C}$. Endogenous peroxidase was blocked by treatment with hydrogen peroxide and methanol.

Table 1 shows details of the monoclonal antibodies 
Table 1 Monoclonal antibodies

\begin{tabular}{llll}
\hline Antibody & Source & Specificity & Reference \\
\hline CAM 5-2 & ICRF & $\begin{array}{c}\text { Low molecular weight } \\
\text { cytokeratin } \\
\text { Leucocyte common } \\
\text { antigen (CD45) }\end{array}$ & 19 \\
PD7/26 & Dakopatts Ltd & 15 \\
MB1 & $\begin{array}{c}\text { Bio-Nuclear } \\
\text { Services Ltd }\end{array}$ & B cell & 1718 \\
MB2 & $\begin{array}{c}\text { Bio-Nuclear } \\
\text { Services Ltd }\end{array}$ & B cell & 17 \\
MT1 & $\begin{array}{c}\text { Bio-Nuclear } \\
\text { Services Ltd }\end{array}$ & T cell & 1718 \\
UCHL1 & PCL Beverley & T cell & 1617 \\
\hline
\end{tabular}

which were applied using a simple indirect immunoperoxidase technique, with overnight incubation at $4^{\circ} \mathrm{C}$. Normal mouse serum was substituted for primary antibodies as a negative control. Control blocks of tonsil fixed in unbuffered formol saline were similarly prepared, as were blocks which were fixed, and then processed through either of the decalcification regimens. Samples of bone marrow trephine from negative staging procedures were included as normal controls.

All slides were independently examined by two of us (PAH, RL). Excellent interobserver correlation was achieved.

\section{Results}

Acceptable immunostaining similar to that reported previously ${ }^{5-19}$ was reproducibly obtained with all of the antibodies in material decalcified by both edetic and formic acids. The use of a methanol/hydrogen peroxide blocking step removed most of the endogenous peroxidase activity, and comparison with normal mouse control sections permitted easy identification of any residual endogenous peroxidase staining. Haemosiderin was also identified and did not cause problems of interpretation.

Table 2 shows the results of immunostaining in 54 selected cases.

\section{NORMAL TREPHINES}

Staining with antileucocyte common antigen appeared to be restricted to lymphoid cells, and many of these reacted with $\mathrm{MB1}$ and MB2 or MT1 and UCHL1. In contrast, MT1 stained all myeloid precursors and occasional megakaryocytes. Small aggregates of lymphoid cells were composed mainly of cells that stained with antileucocyte common antigen, MB1, and MB2. Some cells that stained with antileucocyte common antigen, MT1, and UCHL1 were associated with these predominantly B cell clusters.

\section{TREPHINES WITH NEOPLASTIC INFILTRATION}

No staining was seen with CAM 5.2 in cases other than known carcinomas. Three of these carcinomas (one metastatic small cell lung carcinoma and two metastatic adenocarcinomas) showed cytoplasmic staining with MB2.

In both acute and chronic myeloid leukaemia staining with MT1 only was consistently observed. One case of acute myeloid leukaemia showed weak staining with leucocyte common antigen, and a single case of chronic myeloid leukaemia showed staining with UCHL1.

Table 2 Results of immunostaining 54 cases of decalcified bone marrow trephines

\begin{tabular}{|c|c|c|c|c|c|c|c|}
\hline \multirow[b]{2}{*}{ Tumour type } & \multirow[b]{2}{*}{$\begin{array}{l}\text { No of } \\
\text { specimens }\end{array}$} & \multicolumn{6}{|c|}{ Monoclonal antibodies } \\
\hline & & $5 \cdot 2$ & $\begin{array}{l}\text { Leucocyte } \\
\text { common } \\
\text { antigen }\end{array}$ & $M B I$ & $M B 2$ & UCHLI & $M T 1$ \\
\hline $\begin{array}{l}\text { Normal } \\
\text { AML }\end{array}$ & $\begin{array}{l}5 \\
5\end{array}$ & $\overline{-}$ & $\pm 1-$ & $\begin{array}{l}+1- \\
-\end{array}$ & $\begin{array}{l}+1- \\
-\end{array}$ & $\begin{array}{l}+1- \\
-\end{array}$ & $\begin{array}{l}++ \\
++\end{array}$ \\
\hline CML & 5 & - & - & - & - & $-*$ & ++ \\
\hline ALL T cell & 5 & - & $+1++$ & - & - & $+1-$ & $+/++$ \\
\hline ALL B cell & 4 & - & $+1++$ & $+1++$ & $+1++$ & - & $+1++$ \\
\hline $\begin{array}{l}\text { CLL } \\
\text { HCL } \\
\text { NHL B cell } \\
\text { NHL T cell }\end{array}$ & $\begin{array}{l}5 \\
5 \\
5 \\
4\end{array}$ & $\begin{array}{l}- \\
- \\
-\end{array}$ & $\begin{array}{l}+1++ \\
+1++ \\
+1++ \\
+1++\end{array}$ & $\begin{array}{l}+1++ \\
+1++ \\
+1++ \\
-\end{array}$ & $\begin{array}{l}+1++ \\
+1++ \\
+1++ \\
-\end{array}$ & $\begin{array}{l}-\mathbf{R} \\
-\mathbf{R} \\
-\mathbf{R} \\
+1++\end{array}$ & $\begin{array}{l}-\mathbf{R} \\
-\mathbf{R} \\
-\mathbf{R} \\
+/++\end{array}$ \\
\hline $\begin{array}{l}\text { Hodgkin's disease } † \\
\text { Carcinoma } \ddagger\end{array}$ & $\begin{array}{l}4 \\
6\end{array}$ & $\overline{t+}$ & $\begin{array}{l}-\mathbf{R} \\
-\end{array}$ & $\begin{array}{l}-\mathbf{R} \\
-\end{array}$ & $\begin{array}{l}-\mathbf{R} \\
-1+\end{array}$ & $\begin{array}{l}-\mathbf{R} \\
-\end{array}$ & $\begin{array}{l}-\mathbf{R} \\
-\end{array}$ \\
\hline Neuroblastoma & 1 & - & - & - & - & - & (NSE positive) \\
\hline
\end{tabular}

*One case showed weak staining; $\uparrow$ Reed Sternberg cells negative with all markers; $\ddagger$ Including two metastatic small cell carcinomas and four metastatic adenocarcinomas.

$R=$ staining of reactive lymphoid cells admixed with neoplastic cells; $-=$ no cells staining; $+=$ some cells staining; $++=$ many cells staining.

$\mathrm{AML}=$ acute myeloid leukaemia; $\mathrm{CML}=$ chronic myeloid leukaemia; $\mathrm{ALL}=$ acute lymphoblastic leukaemia; $\mathrm{HCL}=$ hairy cell leukaemia; NHL B/T cell $=$ non-Hodgkin's B $/ \mathrm{T}$ cell lymphoma. 
Five cases of T cell and four of B cell acute lymphoblastic leukaemia (ALL) zlymphoblastic lymphoma were examined. All nine cases of ALL were consistently positive with leucocyte common antigen. All five examples with a $\mathrm{T}$ cell phenotype were positive with MT1, but only weakly positive or negative with UCHL1. Cases with a B cell phenotype showed staining with MB1 and MB2 of variable intensity, but three cases also showed staining with MT1.

A consistent pattern emerged in all B cell lymphoproliferative disorders (chronic lymphocytic leukaemia, hairy cell leukaemia, and $B$ cell non-Hodgkin's lymphoma), with leucocyte common, $\mathrm{MB1}$, and MB2 usually labelling the abnormal cells, and MT1 and UCHL1 being positive on a minor population of admixed reactive lymphocytes. The intensity of the staining with MB1 and MB2 was variable, with MB1 generally being weaker than MB2. In all four cases of T cell lymphoma staining with MT1 and UCHL1 was seen in the neoplastic cells, but the intensity of staining was variable. No staining by MB1 or MB2 was noted. In all cases of Hodgkin's disease, the Reed-Sternberg cells did not react to any of the markers, while associated lymphocytes stained with MB1 and MB2, or MT1 and UCHL1.

In a single case of metastatic neuroblastoma the staining pattern was clearly distinct from that of lymphoblastic lymphoma, with which it might otherwise be confused. It did not react with any lymphoid markers but stained with neurone specific enolase.

\section{Discussion}

The value of bone marrow trephine biopsy is well established, ${ }^{20}$ and several studies have shown the value of immunotopographic assessment, ${ }^{2-42122}$ and the characterisation of antigens such as immunoglobulin, ${ }^{10-12}$ or epithelial markers, which survive conventional fixation and decalcification. ${ }^{9-13}$ In principle, any antigen which can be shown in conventionally fixed and processed material should be detectable in decalcified material. ${ }^{7-9}$ There is, however, wide variation in how well antigens survive these procedures, ${ }^{23}$ and in the effects of different decalcification methods. ${ }^{924}$ This study shows that the newly described antilymphoid cell markers active in formol fixed, paraffin embedded sections can be successfully used to show the presence of antigens in bone marrow trephines decalcified in formic and edetic acids.

The use of the alkaline phosphatase-antialkaline phosphatase method has been advocated in the examination of bone marrow, ${ }^{3}$ but we and others ${ }^{40}$ have not found endogenous peroxidase activity or haemosiderin to cause problems in interpretation.

Pizzolo et $a l^{25}$ reported that some early haemopoietic precursors express leucocyte common antigen. Staining of occasional mononuclear cells was seen, but these appeared to be lymphoid cells and were either MB1, MB2, or MT1, UCHL1 positive. $\mathrm{UCHL} 1^{16}$ and $\mathrm{MB} 2^{17}$ have previously been reported as staining some marrow precursors, but in this series non-lymphoid cells stained rarely. Weak staining of mature myeloid cells with UCHL1 was seen. MT1, in contrast, stained most myeloid cells and occasional megakaryocytes. ${ }^{18}$

The staining of leukaemias, lymphoid proliferations, and other tumours was as expected from the staining of normal marrow, and as reported in previous studies. ${ }^{16-18}$ In particular, the staining of $T$ cell acute lymphoblastic leukaemia by MT1, and weak or absent staining by UCHL1, confirms the findings of previous studies. ${ }^{16} 17$ The antigen recognised by MT1 is probably expressed earlier in thymic ontogeny than that detected by UCHL1. In general, T cell ALL also expresses the leucocyte common antigen and thus, despite the extensive reaction with myeloid elements, MT1 can be of value in the immunohistological examination of bone marrow trephines. The staining of primitive B cell tumours (B-ALL/lymphoblastic lymphoma) by MT1 was not described in a previous study. ${ }^{19}$ The staining of these tumours by MB1 and MB2 permits the distinction of many primitive $B$ and $T$ cell tumours.

There was clear and accurate separation of $T$ cell and B cell non-Hodgkin's lymphomas. It is of particular interest that the degree of marrow disease in most cases of non-Hodgkin's lymphoma was shown to be more extensive than was apparent on simple morphological examination. Bartl et $a^{20}$ described the appearances and evolution of lymphoproliferation in the bone marrow and showed the architectural pattern and quantity of infiltration was of prognostic importance. Immunotopographic examination using these markers may permit more accurate quantitation of lymphomatous infiltration in decalcified marrow trephines. It is unlikely, however, that these reagents will contribute to the problem of assessment of minimal residual disease.

The use of these reagents, coupled with other antibodies such as neurone specific enolase and desmin, may help in the differential diagnosis of bone marrow disease by "small round cell tumours" seen in childhood. The use of frozen section has been advocated for this, ${ }^{26}$ but fresh tissue is often not available.

In summary, we have investigated the use of lymphoid markers active in paraffin sections for the assessment of decalcified bone marrow trephines. These reagents are not ideal, and will not achieve their full potential use until the antigens they recognise are fully characterised. Their careful application, however, may be of practical value in the investigation of bone marrow disease. 
PAH is a research fellow with the Imperial Cancer Research Fund (ICRF) and AJd'A is supported in part by the ICRF. We thank Bio-Nuclear Services Ltd and Euro-Diagnostics Ltd for supplying antibodies MB1, MB2, and MT1.

\section{References}

1 Chilosi M, Pizzolo G, Janossy G, Bofill M, Fiore-Donati L. Enzyme histochemical analysis on cryostat sections of human bone marrow. J Clin Pathol 1982;35:1220-6.

2 Pizzolo G, Chilosi M, Cetto GL, Fiore-Donati L, Janossy G. Immuno-histological analysis of bone marrow involvement in lymphoproliferative disorders. Br J Haematol 1982;50:95-100.

3 Falini B, Martelli MF, Tarallo F, et al. Immunohistological analysis of human bone marrow trephine biopsies using monoclonal antibodies. $\mathrm{Br} J$ Haematol 1984;56:365-86.

4 Wood GS, Warnke RA. The immunologic phenotyping of bone marrow biopsies and aspirates: frozen section techniques. Blood 1982;59:913-22.

5 Ghosh AK, Erber WN, Hatton CSR, et al. Detection of metastatic tumour cells in routine bone marrow smears by immunoalkaline phosphatase labelling with monoclonal antibodies. $\mathrm{Br}$ J Haematol 1985;61:21-30.

6 Moir DJ, Ghosh AK, Abdulaziz Z, Knight P, Mason DY. Immunoenzymatic staining of haematological samples with monoclonal antibodies. Br J Haematol 1982;55:395-410.

7 Mathews JB, Mason GI. Influence of decalcifying agents on immunoreactivity of formalin fixed, paraffin embedded tissue. Histochem J 1984;16:771-87.

8 Mullink H, Henzen-Logmans SC, Tadema TM, Mol JJ, Meijer CJLM. Influence of fixation and decalcification on the immunohistochemical staining of cell-specific markers in paraffin embedded human bone biopsies. J Histochem Cytochem 1985;33:1103-9.

9 Mukai K, Yoshimura S, Anzai M. Effects of decalcification on immunoperoxidase staining. Am J Surg Pathol 1986;10:413-9.

10 Pinkus GS, Said J. Specific identification of intracellular immunoglobulin in paraffin sections of multiple myeloma and macroglobulinaemia using an immunoperoxidase technique. Am J Pathol 1977;87:47-58.

11 Taylor CR, Russell R, Chandor S. An immunohistologic study of multiple myeloma and related conditions, using an immunoperoxidase method. Am J Clin Pathol 1978;70:612:22.

12 Hitzman J, Li C.Y, Kyle RA. Immunoperoxidase staining of bone marrow sections. Cancer 1981;48:2438-46.

13 Sloane JP, Omerod MG, Imrie SF, Coombes RC. The use of antisera to epithelial membrane antigen in detecting micrometastases in histological sections. Br J Cancer 1980;42:392-8.

14 Innes DJ, Mills SE, Walker GK. Megakaryocytic leukaemia. Identification utilising anti factor VIII immunoperoxidase. $\mathrm{Am}$ J Clin Pathol 1982;77:107-10.

15 Warnke RA, Gatter KC, Falini B, et al. Diagnosis of human lymphoma with monoclonal anti leucocyte antibodies. $N$ Engl J Med 1983;309:1275-81.

16 Norton AJ, Ramsay AD, Smith SH, Beverley PCL, Isaacson PG. Monoclonal antibody (UCHL1) that recognises normal and neoplastic $\mathrm{T}$ cells in routinely fixed tissues. J Clin Pathol 1986;39:399-405.

17 Hall PA, d'Ardenne AJ, Butler MG, Habeshaw JR, Stansfeld AG. MB2 a new marker of B lymphocytes and a comparison with other lymphocyte subset markers active in conventionally processed tissue sections. J Clin Pathol 1987;40:151-6.

18 West KP, Warford A, Fray L, Allen M, Campbell AC, Lauder I. The demonstration of $B$ cell, $T$ cell and myeloid antigens in paraffin sections. J Pathol 1986;150:89-101.

19 Makin CA, Bobrow L, Bodmer W. Monoclonal antibody to cytokeratin for use in routine histopathology. J Clin Pathol 1984;37:975-83.

20 Bartl R, Frisch B, Bunkhardt R, Jager K, Pappenberger R, Hofman-Fezer G. Lymphoproliferations in the bone marrow: identification and evolution, classification and staging. $J$ Clin Pathol 1984;37:233-54.

21 Pizzolo G, Chilosi M, Ambrosetti A, Semenzato G, Fiore-Donati L, Perona G. Immunohistologic study of bone marrow involvement in B chronic lymphocytic leukaemia. Blood 1983;62:1289-96.

22 Kronland R, Grogan T, Spier C, et al. Immunotopographic assessment of lymphoid and plasma cell malignancies in the bone marrow. Hum Pathol 1985;16:1247-54.

23 Mason DY. Immunohistology of lymphoid tissue. In: Filipe MI, Lake BD, eds. Histochemistry in Pathology. Edinburgh: Churchill Livingstone, 1983:215-35.

24 Athanasou N, Quinn J, Heryet A, Woods CG, O'D McGee J. The effect of decalcification agents on the immunoreactivity of cellular tissue antigens. J Clin Pathol 1987;40:874-8.

25 Pizzolo G, Sloane J, Beverley P, et al. Differential diagnosis of malignant lymphomas and non lymphoid tumours using monoclonal anti-leucocyte antibodies. Cancer 1980;46:2640-7.

26 Kemshead JT, Goldman A, Fritschy J, Malpas JS, Pritchard J. Use of panels of monoclonal antibodies in the differential diagnosis of neuroblastoma and lymphoblastic disorders. Lancet 1983;i:12-4.

Requests for reprints to: Dr PA Hall, ICRF Research Fellow, Department of Histopathology, St Bartholomew's Hospital, London EC1A 7BE, England. 